\title{
List of Figures, Plates, and Tables
}

\section{Figures}

Figure I.1 Map of Japan's medieval provinces

Figure 3.1 Site of Ōzuka tomb, Ōbe Estate

Figure 3.2 Kiyotani archaeological site, Ōbe Estate, early medieval period

Figure 3.3 Jōdoji subtemples

Figure 3.4 Site of a Jōdoji building

Figure 3.5 Remains of pit dwellings, Ōji Shiro-no-shita

Figure 3.6 Yayoi period pottery, Ōji Shiro-no-shita

Figure 3.7 Tumulus period artifacts, Ōzuka tomb

Figure 4.1 Map of medieval Tōdaiji

Figure 4.2 Tōdaiji organizational chart

Figure 4.3 Classification and disposition of Tōdaiji documents over time

Figure 5.1 Map of Ōgi Village

Figure 5.2 Map of Tsuchimaru Village

Figure 5.3 Map of Hineno Village

Figure 7.1 Map of Kuroda Estate

Figure 9.1 Map of villages drawing irrigation water from Sayama Pond

Figure 11.1 Jōdodō section diagram, Jōdoji, Hyōgo Prefecture

Figure 11.2 Jōdodō ground plan, Jōdoji, Hyōgo Prefecture

Figure 11.3 Amida Triad, Jōdoji, side view

Figure 11.4 Amida Triad by Kaikei, c. 1221

Figure 12.1 Royal family genealogy

Figure 12.2 Jōsaimon-in's estates (all)

Figure 12.3 Map of Jōsaimon-in's estates, Yamashiro Province

Figure 12.4 Map of Jōsaimon-in's estates, Ōmi Province 
Figure 12.5 Map, properties of Hachijōin and Kōkamon-in in the capital

Figure 12.6 Map of Hachijō-in's estates

Figure 13.1 Map of the Saionji family estates

Figure 13.2 Map of maritime trade routes

Figure 13.3 Map of the River Yodo basin

Figure 13.4 Map of waterways around the capital

Figure 15.1 Map of northern Naga District, including Nate Estate

Figure 15.2 Map of the upper Kinokawa Valley

Figure 16.1 Map of Harima Province

\section{Color plates}

Plate 1 Seated image of Chōgen, Jōdoji, Hyōgo Prefecture

Plate 2 Terraces of Ōbe Estate

Plate 3 Pre-Kamakura archaeological sites on Ōbe Estate

Plate 4 Kamakura-period archaeological sites on Ōbe Estate

Plate 5 Model of the abandoned Kōdoji Temple, Hyōgo

Prefecture

Plate $6 \quad$ Edo-period illustration of Jōdoji buildings

Plate $7 \quad$ Nigori Pond, Ōbe Estate

Plate 8 Map of the site of Hine Estate

Plate 9 Map of Hineno Village on Hine Estate, dated 1316

Plate 10 Site of three inner villages, Hine Estate

Plate 11 Terraced rice fields on the site of Hine Estate

Plate 12 Location of Tsuchimaru Village, Hine Estate

Plate 13 Location of Hineno Village, Hine Estate

Plate 14 Yugawa Canal, Hineno Village, Hine Estate

Plate 15 Plaque with account of Chōgen's repairs of Sayama Pond, dated 1202

Plate 16 Amida Triad by Kaikei, c. 1195, Jōdoji, Hyōgo Prefecture

Plate 17 Chōgen, first half of thirteenth century

Plate 18 Jōdodō, 1194, Jōdoji, Hyogo Prefecture

Plate 19 Amida Triad, 1148

Plate 20 Head of Amida (before restoration) by Kaikei, c. 1202

Plate 21 Amida Triad, Ming period, China

Plate 22 Amida Nyorai by Kaikei, 1201

Plate 23 Masks by Kaikei and others, c. 1201

Plate 24 Map of Kōkamon-in's estates 
Plate 25 Map of all ports shipping salt to the Hyōgo checkpoint

Plate 26 Map of major ports shipping salt to the Hyōgo checkpoint

Plate $27 \quad$ Map of all ports shipping rice to the Hyōgo checkpoint

Plate 28 Map of major ports shipping rice to the Hyoggo checkpoint

Plate 29 Map of Kii Province

\section{Tables}

Table 4.1 Superior management rights to Öbe Estate, twelfth to fifteenth centuries

Table 4.2 Current locations of Tōnan'in and corporate temple documents

Table 4.3 Selected documents related to Ōbe Estate, Muromachi Period

Table 5.1 Chronology of Hine Estate in Izumi Province

Table 5.2 Archaeological sites on Hine Estate

Table 5.3 Archaeological remains of the Hine site according to type

Table 5.4 Hine Estate communities: Kamakura period

Table 5.5 Hine Estate communities: Muromachi, Sengoku periods

Table 6.1 Extant decrees: "Measures for the Increased Production of Miscellaneous Grains"

Table 6.2 Cultivation at Ōbe Estate in the Nanbokuchō period

Table 6.3 Approximate acreage of "loss" and "flooded" fields at Öbe Estate

Table 8.1 Strata within Tōdaiji in the Kamakura period

Table 11.1 Sculptures at Chōgen's Bessho (Namu Amidabutsu Sazenshū)

Table 13.1 Landholdings of the Saionji family

Table 14.1 All goods shipped on Onomichi boats to Hyōgo, 1445

Table 16.1 Akutō in the second Ōbe Estate case, 1322 
